Article

\title{
Exploring MOOCs That Promote Innovative Public Services
}

\author{
Masami Yoshida ${ }^{1, * \mathbb{D}}$, Anuchai Theeraroungchaisri ${ }^{2}$, Thapanee Thammetar $^{3}$ and Jintavee Khlaisang ${ }^{4}$ \\ 1 The Faculty of Education, Chiba University, 1-33 Yayoi, Inage, Chiba 263-8522, Japan \\ 2 Faculty of Pharmaceutical Sciences, Chulalongkorn University, 254 Phayathai Road, Pathumwan, \\ Bangkok 10330, Thailand; anuchai.t@pharm.chula.ac.th \\ 3 Faculty of Education, Silpakorn University, 6 Rajamankha Nai Road, Amphoe Muang, \\ Nakhon Pathom 73000, Thailand; thammetar_t@silpakorn.edu \\ 4 Educational Intervention and Innovation Research Unit, Faculty of Education, Chulalongkorn University, \\ 254 Phayathai Road, Pathumwan, Bangkok 10330, Thailand; jintavee.m@chula.ac.th \\ * Correspondence: yoshida-m@faculty.chiba-u.jp
}

Citation: Yoshida, M.;

Theeraroungchaisri, A.; Thammetar,

T.; Khlaisang, J. Exploring MOOCs

That Promote Innovative Public

Services. Sustainability 2021, 13, 13939.

https://doi.org/10.3390/

su132413939

Academic Editors: Miltiadis D. Lytras and Rui Cunha Marques

Received: 12 November 2021

Accepted: 12 December 2021

Published: 16 December 2021

Publisher's Note: MDPI stays neutral with regard to jurisdictional claims in published maps and institutional affiliations.

\section{Copyright: (c) 2021 by the authors.} Licensee MDPI, Basel, Switzerland. This article is an open access article distributed under the terms and conditions of the Creative Commons Attribution (CC BY) license (https:// creativecommons.org/licenses/by/ $4.0 /)$.

\begin{abstract}
The promotion and dissemination of a government's basic policy are essential to implement innovative public services to establish sustainable country development and to ensure that the benefits are shared among citizens. This study focused on the MOOCs project in Thailand, and five courses were selected for exploration. Qualitative content analysis and sentiment analysis were applied to understand how information and communications technology in government services was promoted in the courses. These methods also explained the differences in the content of each course. It turned out that the strategy of improving service quality was the most-emphasized strategy in courses with an explanation of positive sentiment. The number of users who received a positive explanation of improving service quality was estimated at 711 and rated as a satisfactory result. The result of the qualitative content analysis was assembled into groups that could reveal the government's pleiotropic orientation in their work on basic policy. All of these groups are involved in the international criteria for a government's digital transformation, and other activities have also been highlighted as future challenges. The possibility of using MOOCs for policy promotion and education is suggested to bridge the gap between Thailand and other countries.
\end{abstract}

Keywords: public services; MOOCs; sentiment analysis; sustainable country development; qualitative content analysis

\section{Introduction}

How does the government implement public services to establish sustainable country development and ensure that the benefits are spread across citizens? As a correspondence measure for this, the use of modern innovative technologies by governments in many countries around the world has resulted in widespread public services for citizens, businesses, industries, and other municipal offices [1-3]. Advanced digital technologies, such as the drastic increases in the performance of information and communications technology (ICT), also contribute to our daily lives. In addition, ICT is becoming a powerful enabler not only to make transactions and activities more efficient and effective but also to initiate a paradigm shift in the long-term basis of development, including its fundamental design, strategies, implementation, and learning [4]. Big data and blockchain are accelerating the government revolution and creating a new generation through the smartification of public services [5]. E-government makes existing public services more accessible, efficient, and convenient [6], and it is being disseminated worldwide [7]. This revolution in ICT, which encompasses all regions and populations, has affected the interaction between modern governments and citizens [8].

Digital transformation (DX) is becoming a central element in improving work processes, and there is a direct connection between technological innovations and methods 
for managing digital working processes and integrated digital working systems [9]. Previous studies have illustrated how government officials at all levels around the world face different types of data and technology problems $[10,11]$. Hence, data and technology play vital roles in public sector services; thus, developing well-trained professionals is critical to success [12]. In addition, investments in support and data-skills training, as well as technical skills training across a broad cross-section of civil society, are required so that citizens can effectively understand and use governmental data and policy information [13]. In these areas, education and training are essential for the diffusion of innovative public services. For this measure, universities are expected to contribute to sustainable country development through the training and further education of civil servants, citizens, and students.

\subsection{Expanding Roles of Education as a Partner of Government}

University funding is divided into three sources: government, private, and industrial partners who pay for knowledge and new technologies, and parties who provide funding in exchange for solutions to major social problems [14]. These three forms of financing are at the corners of a triangle, within which mixed forms are possible. Universities are expected to contribute to the dissemination of knowledge about innovative public services and to have the opportunity to obtain hybrid funding from all three components, as well as the opportunity to train citizens and civil servants. From the perspective of future higher education, the following four phenomena stand out [14]:

- The potential power of a fundamental shift in achieving economic balance among the economic blocks seems inevitable;

- The far-reaching urbanization will certainly play a significant role in the development of the world's future knowledge centers;

- ICT and knowledge will have a large impact on the social order;

- The development of the labor market versus the educational level is an important factor.

In this way, innovation and interaction with society make the university better and more creative, and they also increase the support of universities in society through economic returns for knowledge [14]. The shift in lifelong education policy toward economic dominance over social and wellbeing learning goals, as well as the trajectory of disadvantage and growing learning divide, is evident [15]. As a practical measure, massive open online courses (MOOCs) can offer lifelong education opportunities if all of the courses available to adults are viewed as valuable in their own right and practically free of charge if individuals wish to complete them.

\subsection{Three Categories of Innovative Public Services}

The role of ICT in the delivery of public services needs to be examined in context. In particular, the fundamental goal of innovative public service delivery, which guides service context, is essential, and the following three categories are proposed in order to understand it [1]:

S1. Innovative delivery channels: In addition to the services via conventional media, the digital channel can improve the provision of services on the Internet. The back offices of services can be digitized and connected to provide innovative solutions to improve service delivery.

S2. Improving service quality: Many service components require direct human interaction in healthcare and education and require building personal and trusting relationships through dialogue and empathy, where ICT can be a valuable support tool for frontline workers. ICT solutions are used to better handle and analyze large amounts of data. The redistribution of human and other resources into personal interaction with users is where this provides the greatest service value.

S3. Capacity building: ICT is a powerful additional channel that enables new types of innovative services and the development of strategic innovative services. All public service providers and civil servants have to adjust to the provision of new services. 
Gascó-Hernández et al. compared how training activities in Spain, Italy, and the United States attempted to increase awareness and use of open government data and suggested adapting the course in MOOCs [16]. The current study then focused on public MOOCs, identified related training courses that advance the government's basic policy, and examined the relationship between course content and an explanation of the innovative public services based on the three categories above.

While Thailand encourages citizens to acquire the knowledge and skills necessary for the Sustainable Development Goals (SDGs), activities include establishing sustainable education and the use of communications technologies [17]. For the current study, MOOCs in Thailand were selected as the target of the study, which are operated by the Ministry of Higher Education, Science, Research, and Innovation (MHESI), which is responsible for educating citizens and civil servants in addition to university students.

\section{Innovation in Thailand Policy and Education}

The policy of innovative sustainable development was mandated by the National Strategy of Thailand (2018-2037) [18]. This policy was developed for continuous country development with consistent measures from the National Economic and Social Development Plan (2017-2021), which includes human capital, inequality, sustainable economic competitiveness, infrastructure and logistics, and international cooperation [19]. The policy objectives included adaptation to international standards, and the policy is aimed at building higher international competitiveness. To this end, the use of ICT should be enhanced to create competitive advantages in various industries and develop high-quality public services for citizens.

On the other hand, the development of human capital was expanded to include education and the acquisition of life skills as social empowerment to improve quality of life. In particular, ICT is promoted as an important driving force to impart knowledge and wisdom to citizens and to lead society toward equality and a sustainable economy. Universities are expected to offer lifelong education and to cooperate with the workforce by using the MOE online platform in the revised country reform plan [20] to create the framework for action.

\section{Public MOOCs Services}

In line with the principles of the National Strategy of Thailand and the ICT Policy Framework 2020 [21], the Long-Range Plan in Higher Education (2018-2037) is focused on human resource development and the development of organizational systems [22]. This is in line with the National Digital Economy and Society Development Plan and Policy (2018-2037), which proposes the guidelines to take education to the next step through digital education and lifelong learning [23]. In particular, these policies are aimed at citizens to adapt to online education for living and learning and to develop sustainable services using a novel system and structure [24]. With regard to this service area, the Thailand Cyber University (TCU) project, the online education service project of the Ministry of Higher Education, and technical services were launched in 2005. The TCU expanded its service to include MOOCs in 2017, naming them T-MOOCs (http:/ / thaimooc.org, accessed 14 October 2021) [25]. The T-MOOCs aim to create a lifelong learning society to improve the expertise of individuals in both the public and the private sectors. As a well-known advantage of MOOCs, citizens have the opportunity to continue their education, and the advantage of MOOCs' platforms can bundle individual courses into MicroMasters [26]. The T-MOOCs project is also included in the Thailand 4.0 model in the Educational Development Plan of the Ministry of Education (2017-2021), in which the MHESI works with the private sector, other government sectors, and civil society to support innovations to respond to the global change [27]. Then, the T-MOOCs are designed to offer new opportunities for the Thai citizens to learn throughout their lives by using ICT that improves access to educational services equally and efficiently in formal, nonformal, and informal contexts [28], and a total of 526 courses are currently offered. Courses from various organizations were involved, 
for example, the Office of the Civil Service Commission (OSCS) (government official development courses), the Ministry of Information and Communication Technology (digital literacy courses), the Digital Economy Promotion Agency (DEPA) (digital economy and social promotion courses), the Distance Education Institute, the Office of Nonformal and Informal Education, the Thailand Professional Qualification Institute (public organization), and the Office of the National Digital Economy and Society Commission (courses from the Digital Community Center) [29].

\section{Research Questions and Aims}

This study selected courses from T-MOOCs that promote and disseminate the government's basic policy and examined how innovative public services were targeted, explaining and discussing their impact. The following research questions were addressed:

(a) What target groups are intended for the courses?

(b) Which service category of innovative public services is mainly selected?

(c) What strategies do course writers use to explain innovative public services?

(d) To what extent does the positive explanation of innovative public services reach users?

(e) What is the future affordance in using T-MOOCs to advance the government's basic policy?

This study framed the following aims to examine these research questions:

(a) Identify the content field and target users;

(b) Provide explanations regarding innovative public services and identify the service category;

(c) Identify the strategies and directions of course writers in designing a course;

(d) Estimate the possible number of users who will receive a positive explanation of the selected innovative public service;

(e) Identify the benefits of using T-MOOCs, including an international perspective of using DX in government.

\section{Method}

The present study carried out two analyses for the research questions and aimed to investigate selected courses in T-MOOCs. For the investigation, the course documents and the transcription of instructional videos in the courses were collected and translated into English by the authors, and datasets were prepared. While the qualitative content analysis provided a comprehensive overview of the datasets, the emphasis on explaining ICT in the government's basic policy could be measured directly. We also conducted sentiment analysis to obtain an accurate measure of the expressed sentiment related to each sentence within the datasets. In addition, three categories of innovative public services were used as an analytical variable. Thus, in the current study, $1 \times 3 \times 3$ treatments were used through qualitative content analysis, sentiment analysis (positive, neutral, and negative), and categories of innovative public services (S1, S2, and S3).

All analyses served to identify the concept of the course writers. These concepts were concealed within bodies of the course contents, where these analytical methods helped to uncover specific elements. It has been reported that a combination of analyses improves the reliability of qualitative content analysis by providing the results of sentiment analysis, which further highlights important themes [30].

\subsection{Target Courses}

Five courses in T-MOOCs were selected as target courses for the current study (Table 1). Although all courses were designed to promote and disseminate the government's basic policy to citizens, students, and officials in order to ensure sustainable country development, no courses articulated any policies or acts; instead, they explained priorities by focusing on the interpretation of course writers. 
Table 1. Reviewed courses in T-MOOCs.

\begin{tabular}{|c|c|c|c|c|}
\hline Course & Title & Developer & Target & Start \\
\hline $\mathrm{A}$ & $\begin{array}{l}\text { Digital government } \\
\text { transformation }\end{array}$ & $\begin{array}{c}\text { Office of the Civil Service } \\
\text { Commission (in cooperation } \\
\text { with Sukhothai Thammathirat } \\
\text { Open University) }\end{array}$ & $\begin{array}{l}\text { Senior executives, middle } \\
\text { executives, planning departments, } \\
\text { personnel departments, marketing } \\
\text { departments, organizational } \\
\text { development departments, IT } \\
\text { (digital) executives, core staff, and } \\
\text { the general public }\end{array}$ & 15 April 2020 \\
\hline B & $\begin{array}{c}\text { Digital } \\
\text { transformation }\end{array}$ & $\begin{array}{l}\text { Digital Government } \\
\text { Development Agency }\end{array}$ & $\begin{array}{l}\text { Government officials, government } \\
\text { personnel, and the general public }\end{array}$ & 21 December 2020 \\
\hline $\mathrm{C}$ & $\begin{array}{l}\text { National strategy and } \\
\text { implementation }\end{array}$ & $\begin{array}{l}\text { Office of the National } \\
\text { Economic and Social } \\
\text { Development Council }\end{array}$ & Students and the general public & 4 June 2020 \\
\hline $\mathrm{D}$ & Change management & Mahidol University & Students and the general public & 15 April 2020 \\
\hline $\mathrm{E}$ & Public administration & Naresuan University & $\begin{array}{l}\text { Undergraduate students and the } \\
\text { general public }\end{array}$ & 15 April 2020 \\
\hline
\end{tabular}

Note: All courses were finalized at the end of September 2021.

\subsection{Qualitative Content Analysis}

The qualitative content analysis was conducted to analyze the manifest and latent meaning of course content. While manifest content denotes that the visible and superficial content of datasets is coded, latent content denotes that the underlying meaning of the datasets is coded [31]. Subsequently, the qualitative content analysis initiates the classification of datasets into identified groups of similar meaning [32], allowing the analysis of the content to establish similar results across group codes [33]. In other words, it is a method of systematically describing the meaning of qualitative material [34]. In the current study, the experts of the T-MOOCs were selected to develop codes through a systematic process of coding, finding, categorizing, and defining themes of the process for the qualitative content analysis [35-37]. The coding works focused on one aspect of the use of ICT in the implementation of the government's basic policies.

As a qualitative content analysis process, the inductive approach is initially carried out for the coding in which codes are directly related to the sentences of datasets. The deductive approach begins continuously with preconceived codes or the relevance of study targets, research, or the literature [38]. Simultaneously, manifest coding, in which the visible and superficial content of the dataset is coded, is mainly used in the inductive approach, whereas latent coding, in which the underlining meaning of the dataset is coded, is used in the deductive approach to grouping codes [31].

In this study, the inductive (manifest content) approach identified the overall public sections, public activities, systems, methods, and their enhancement, and the deductive (latent content) approach identified policies, aims, references, and strategies. Finally, the qualitative content analysis, using Atlas.ti 9 software, was conducted to establish grouped codes.

\subsection{Sentiment Analysis}

Furthermore, sentiment analysis was used to identify opinions, sentiments, and emotions expressed in the content. Sentiment analysis conducts text analysis and uses computational techniques to automate the extraction or classification of sentiments from sentiment ratings [39]. Sentiment analysis has been used in various analytical areas, such as consumer information, marketing, books, applications, websites, and social information [40]. After the dissemination of Internet services, the usage has continued to increase with the increasing number of online messages. In the current study, datasets were subdivided into sentences, and the process of detecting sentiment polarity was initiated [41]. 
The spaCy open-source library for natural language processing in Python, the TextBlob library, and the valence aware dictionary for sentiment reasoning (VADER) library were used for the analysis.

\section{Results}

The results of the analyses are summarized in the sections below.

\subsection{Qualitative Content Analysis}

The qualitative content analysis on datasets from the five courses resulted in a total of 183 codes with 88 unique codes (Table 2). All codes from the manifest coding are listed in Appendix A.

Table 2. The number of codes in the dataset.

\begin{tabular}{cccc}
\hline Course & $\begin{array}{c}\text { The Number of } \\
\text { Course Writers }\end{array}$ & $\begin{array}{c}\text { The Number of } \\
\text { Words in the Dataset }\end{array}$ & $\begin{array}{c}\text { The Number of } \\
\text { Codes in the Dataset }\end{array}$ \\
\hline A & 1 & 17,873 & 33 \\
B & 1 & 7348 & 46 \\
C & 3 & 8314 & 74 \\
D & 1 & 24,966 & 29 \\
E & 2 & 13,380 & 1 \\
\hline Totals & 8 & 71,881 & 183 \\
\hline
\end{tabular}

All courses introduced the course writer's interpretation of the government's basic policy, while the expected target area and related enhancement of technologies in the courses varied. Whereas Course A was aimed at introducing public executive staff to the use of ICT in government missions to develop the digital government, the content of the course was diverse and included strategies, job improvement, preparation for ICT services, and developing new services. Similar to Course A, Course B introduced the use of ICT in the public sector but focused more on empowering frontline public service workers through ICT. The concept of sustainable digital organization was strengthened to improve the skills of civil servants. Since Course $C$ was designed for social people, it expatiated upon implementing ICT and human development to solve internationally recognized issues and the country's economic development through ICT investments in the various local industries. These three courses were related to the active use of ICT for the government's basic policy. On the other hand, Course D and Course E described optimal administration and management to align the objectives of the government's basic policy. ICT was partly explained in these courses as a tool for evaluating policy implementation. One result of these courses was that innovative technologies were little involved in their structure.

Although all five courses focused on the government's basic policies, the situation of enhancing ICT in public services varied from course to course. Thus, contextual differences were explored through a series of analyses.

\subsection{Innovative Public Service Categories}

Whilst S2 had the highest frequency count rate (63.4\%) in three categories (Figure 1), S2 was occupied by Courses A and B with $82 \%$ of the frequency count rate. Courses A and B presented many innovative public service ideas that covered $49.3 \%$ and $36.6 \%$ of the frequency count rates, respectively. Although Course $\mathrm{C}$ had the most prominent frequency count of codes (Table 2), and the course introduced limited discussions of current local innovative public services (Figure 1) but presented world-renowned advanced technologies to be used in future public services. Although Courses D and E contained many words in datasets (Table 2), these courses contained limited codes related to innovative public services (Figure 1). 


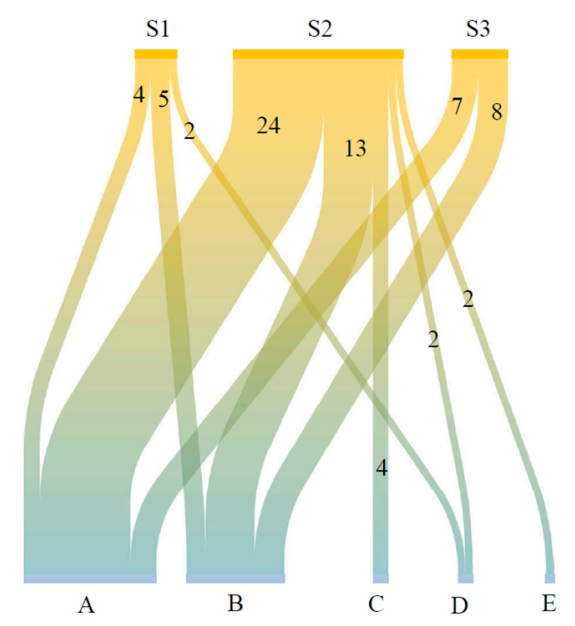

Figure 1. Sankey diagram of innovative public services (top) and courses (bottom).

\subsection{Sentiment Analysis}

Although sentences with a positive expression occurred more strongly than those with a negative and neutral expression (Figure 2), no extreme bias of the sentiments could be determined on the basis of the sentiment analysis. This meant that the innovation of public services was explained in terms of advantages and disadvantages.

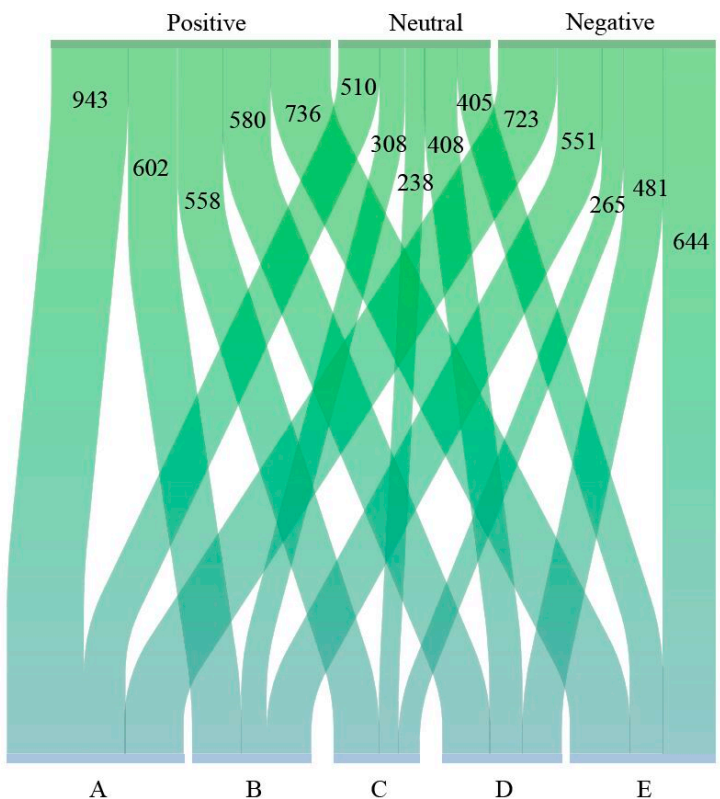

Figure 2. Sankey diagram of sentiment analysis (top) and courses (bottom).

Course A had the highest number of sentiment scores of all courses $(943, M=619$, $95 \%$ CI: 492, 746), and the positive sentiment rate was $43.34 \%$. Course B had the highest frequency count rate of negative sentiment (37.7\%, $M=32.9 \%, 95 \%$ CI: 23.9, 41.9). Course $C$ had the highest rate of positive sentiment (52.6\%, $M=43.6 \%, 95 \%$ CI: 34.0, 53.2), but it had the lowest frequency count of sentiment (1061, $M=1590,95 \%$ CI: 1074, 2107). The results show that the concept of advanced technologies regarding future perspectives was positively explained by the course writers. The other two courses, Courses D and E, had sentiment scores, but these appeared in the optimal administration and management statements. 


\subsection{Relationship between Sentiment Analysis and Innovative Public Services}

In order to determine the distribution of explanations for innovative public services in T-MOOCs, the identification of sentiment sentences in datasets was classified into categories of innovative public services (Table 3). In addition, an investigation of the relationships in the results were carried out using cooccurrence calculations. The c-coefficient (cooccurrence coefficient) indicates the strength of the relationship between the results. The value of the c-coefficient is between zero and one, where the number is closer to one when two results appear wherever they are used. The c-coefficient is a method for performing quantitative analysis on qualitative data [42,43].

Table 3. Relationship between sentiment analysis and innovative public services (c-coefficients in parentheses).

\begin{tabular}{ccccc}
\hline & Positive & Neutral & Negative & Totals \\
\hline \multirow{2}{*}{ S1 } & 75 & 44 & 76 & 195 \\
& $(0.02)$ & $(0.02)$ & $(0.03)$ & 1227 \\
S2 & 543 & 254 & 430 & $(0.19)$ \\
& $(0.18)$ & $(0.15)$ & 246 & 775 \\
S3 & 352 & 177 & $(0.10)$ & 2197 \\
\hline
\end{tabular}

Apparently, S2 and S3 had a higher c-coefficient than S1. Notably, S2 presented a higher number of scores, with larger positive and negative than neutral scores. This result confirms those of Sections 5.2 and 5.3, showing that S2 is the current target of innovative public services in courses.

\subsection{Reach}

The current study identified S2 as an essential strategy to be promoted and disseminated through T-MOOCs; hence, it was introduced into continuous analysis. The effect on the promotion of $\mathrm{S} 2$ was estimated on the basis of rates in the datasets, the positive rates, and the number of registered users (Table 4).

Table 4. Estimated number of users to reach a positive explanation of S2.

\begin{tabular}{ccccc}
\hline Courses & $\begin{array}{c}\text { Rate of S2 in } \\
\text { the Dataset of } \\
\text { a Course }\end{array}$ & $\begin{array}{c}\text { The Positive } \\
\text { Rate in S2 } \\
\text { Part }\end{array}$ & $\begin{array}{c}\text { Registered } \\
\text { Users }\end{array}$ & $\begin{array}{c}\text { Estimated Number of } \\
\text { Users to Reach } \\
\text { Positive Explanation of S2 }\end{array}$ \\
\hline A & 0.238 & 0.33 & 1336 & 106.0 \\
B & 0.371 & 0.33 & 3975 & 491.6 \\
C & 0.141 & 0.40 & 1831 & 103.3 \\
D & 0.0121 & 0.40 & 886 & 4.3 \\
E & 0.00553 & 0.40 & 2432 & 5.4 \\
\hline Total & & & 10,460 & 710.6 \\
\hline
\end{tabular}

Although the result appears smaller than the total number of registered users, 710.6 is a large-enough number for distribution across workshops. In addition, training in TMOOCs followed the trend of developing policies for innovative public services to enable citizens to access information and participate in the government [44,45]. More specifically, the reach to civil servants was 597.6, and the reach to citizens was 113.0. The importance of online training for civil servants and citizens to promote a deeper integration of digital technologies into public services was also highlighted in a previous study [46]. 


\section{Discussion}

T-MOOCs, which include instructional models, lifelong learning, communication, learning records, and learning analytics, are expected to develop learners and support decision making among government officials [23]. The current study further explores the explanatory concept of the course writers and how the government's basic policy was oriented.

\section{Group Code Analysis}

The 88 unique codes collected in the current study were combined into six groups (Table 5).

Table 5. Results of group coding.

\begin{tabular}{ccc}
\hline Group Code Name & No. of Unique Codes & Involved Code Samples \\
\hline Functions of service systems & 29 & $\begin{array}{c}\text { Cost effectiveness, digital DNA, digitalized organization, leader } \\
\text { competencies, project planning, and recruiting technicians }\end{array}$ \\
\hline Policy-related explanation & 10 & $\begin{array}{c}\text { International agreement, sustainability of organization, Thailand } \\
\text { 4.0 policy, and national strategy of Thailand }\end{array}$ \\
\hline Functions of services & 24 & $\begin{array}{c}\text { Capital connection, citizen access, disruptive technology, } \\
\text { education as a service, lifelong learning, and using Big Data }\end{array}$ \\
\hline Innovative tools & 3 & $\begin{array}{c}\text { NIST (National Institute of Standards and Technology), PMQA } \\
\text { (Public Sector Management Quality Award), and TPMAP (Thai } \\
\text { People Maps and Analytics Platform) }\end{array}$ \\
\hline Relation with corporates & 13 & $\begin{array}{c}\text { Collaboration and cooperation, medical industry, tourism, } \\
\text { corporate culture, and e-commerce }\end{array}$ \\
\hline Targets in society & 9 & $\begin{array}{c}\text { Aging society, environment restoration, gender equality, health, } \\
\text { safe society, social equality, wealth of citizen, and wellbeing }\end{array}$ \\
\hline
\end{tabular}

Table 6 shows the rates for each group code in the courses. The group code "functions of service systems" concerned indispensable internal factors of the innovative public services, whereas the group code "functions of services" concerned aspects of the innovative public service itself. These results supported the analysis of Course C, which had the highest number of codes (Section 5.1) and the lowest number of innovative public service categories (Section 5.2) due to the group code "target in society," which aimed to use group code "functions of services" as future perspectives. Although there were noticeable differences between the courses, the results underline the specific features of individual courses in an understandable way.

Table 6. Rates for the deployment of group codes in courses (\%).

\begin{tabular}{cccccccc}
\hline $\begin{array}{c}\text { Courses/ } \\
\text { Group Codes }\end{array}$ & $\begin{array}{c}\text { Functions of } \\
\text { Service } \\
\text { Systems }\end{array}$ & $\begin{array}{c}\text { Policy-Related } \\
\text { Explanation }\end{array}$ & $\begin{array}{c}\text { Functions of } \\
\text { Services }\end{array}$ & $\begin{array}{c}\text { Innovative } \\
\text { Tools }\end{array}$ & $\begin{array}{c}\text { Relation } \\
\text { with } \\
\text { Corporates }\end{array}$ & $\begin{array}{c}\text { Targets in } \\
\text { Society }\end{array}$ & $\begin{array}{c}\text { Table } \\
\text { Relative }\end{array}$ \\
\hline A & 4.47 & 6.15 & 2.79 & 0.00 & 2.24 & 2.79 \\
B & 15.08 & 1.12 & 3.91 & 0.00 & 5.59 & 0.00 & 25.70 \\
C & 2.79 & 3.35 & 17.32 & 0.56 & 5.03 & 11.73 & 40.78 \\
D & 6.15 & 1.12 & 0.56 & 1.68 & 2.79 & 2.24 \\
E & 0.56 & 0.00 & 0.00 & 0.00 & 0.00 & 0.00 & 0.56 \\
\hline Totals & 29.05 & 11.73 & 24.58 & 2.24 & 15.64 & 16.76 \\
\hline
\end{tabular}

The result shows that the government is pleiotropically oriented toward working on basic policy and that the development of innovative public services should be handled with businesses, industries, citizens, and public contributions. The reason for the pleiotropism lies in the recognition of the SDGs by the Thai government, which is also a 
part of their societal goals. The following statement is mentioned in the voluntary report to the United Nations:

Thailand's application of the Sufficiency Economy Philosophy as our homegrown approach that focuses on human empowerment, resilience, and environmental conservation, along with application of technology and local wisdom ... (Cited from Srivihok [47])

The discrepancy in the diffusion priorities of ICT between businesses and the public can be explained by their shared vision of creating economic development. On the flip side, the ASEAN country survey rates Thailand as catching up in ICT diffusion performance for business and citizens, and government ICT use is rated as lagging behind with the lowest performance [4]. However, no course refers to this internationally comparative stagnation. Indeed, more enhancement of the government's innovation is necessary.

This government's innovation has a global concern. In this regard, GovTech (a portmanteau of the words "government" and "technology") is recognized as a wholegovernment approach that uses ICT to modernize the public sector and promote efficient government [48]. The aim is to improve the delivery of services to citizens and businesses, as well as to increase efficiency, transparency, and accountability [49]. An index to assess GovTech maturity was proposed by the World Bank to promote DX, whereby 198 countries including Thailand are monitored, and all activities of the above group codes and other demanding activities not included in the courses are also presented in the listed 48 indicators [50]. DX is currently a real challenge for the governments of the world.

GovTech's benchmarks for success are internal operational efficiency, efficiency gains, and cost savings [51]. T-MOOCs can afford these requirements and future contributions to policy promotion and training. Furthermore, as the existing professional training appeals to more mainstream civil servants who do not do work for GovTech, a new standard training program was required, recognizing that much is changing rapidly and becoming out of date [52]. This information also highlights the benefits of using T-MOOCs, which can provide timely training that is always accessible.

\section{Final Remarks}

Relevant and useful data were assembled through our analysis in order to focus on important factors related to the research questions and aims. The results of this study identified impacts on the intended target users and a selected innovative public service category. Course strategies were discussed by comparing with the policies of world organizations. The estimated number of users who received a positive explanation of the main strategy was calculated.

On the other hand, T-MOOCs can offer the framework for online discussion in a system in order to connect various people in online environments and to become a place for exchanging opinions. While T-MOOCs have lateral affordance to pursue the dissemination of innovative public services, the present study builds on the central implication that T-MOOCs can deepen the discussion about how new innovative public services work for the wellbeing of citizens and how the government can bridge the GovTech gap between Thailand and other countries. In conclusion, target courses are undoubtedly becoming one of the most unique approaches to promoting a government's basic policy, as T-MOOCs are an easy extension of traditional training, are cost-effective, and have practical relevance. We hope that staff members of T-MOOCs and course writers will use our insights to shape their future courses and revisions.

We also believe that our applied study methods of qualitative content analysis and sentiment analysis can provide an essential reference case for the multiple stakeholders of other courses in MOOCs in the world, particularly courses on open educational initiatives, large- and small-scale government programs, and course designers developing strategies to improve usability.

Author Contributions: Conceptualization, M.Y.; methodology, M.Y.; software, M.Y.; validation, M.Y., A.T., T.T. and J.K.; formal analysis, M.Y.; investigation, M.Y.; resources, M.Y., A.T. and T.T.; data 
curation, M.Y. and A.T.; writing—original draft preparation, M.Y.; writing—review and editing, J.K.; visualization, M.Y.; supervision, T.T.; funding acquisition, M.Y. All authors have read and agreed to the published version of the manuscript.

Funding: This research was funded by JSPS KAKENHI, Grant-in-Aid for Challenging Research (Pioneering), Grant Number 20K20512.

Institutional Review Board Statement: All procedures performed in this work were done in accordance with the ethical standards of the institutional and/or national research committee and complied with the 1964 Helsinki declaration and its later amendments or comparable ethical standards. Informed consent was obtained from Thailand Cyber University Project included in the data-collection process.

Informed Consent Statement: Not applicable.

Data Availability Statement: Not applicable.

Acknowledgments: We wish to thank the timely advice given by Gerard L. Hanley, Executive Director, MERLOT and Skills Commons; Director, California State University Long Beach Center for Usability in Design and Accessibility; Professor Emeritus of Psychology to improve our article.

Conflicts of Interest: The authors declare no conflict of interest.

\section{Appendix A}

The list of codes used in the manifest coding process

NIST/PMQA/TPMAP/Agriculture/Collaboration and cooperation/Corporate architecture/Corporate culture/Corporate leader/Digital corporate finance/E-commerce/ Industries enhancement/Involving corporates/Logistics service/Medical industry/Service provider/Tourism/Administrative security/Architecture/Change digital/Cost effectiveness/Designing importance/Digital DNA/Digital enterprise transformation/Digital government problems/Digital government transformation/Digital service provision/ Digitalized organization/Foreign examples/Human connection/Leader competencies/ Management change/Monitoring and evaluation/Online\&offline/Open technology/Potential leaders/Project planning/Public administration/Public management/Public service categories/Recruiting technicians/Reduce step/Restructuring organization/Risk reduction/SLA/Team work/Governance/Government vision/International agreement/National Economic and Social Development Plan/National Policy for Education/National Strategy of Thailand/Sustainability by technology/Sustainability of organization/Sustainable digital government/Thailand 4.0 policy/Building competitiveness/Capacity building/Capital connection/Capital\&people movement/Citizen access/Citizen involvement/Community enhancement/Cyber security/Data scraping/Developing social capital/Digital service examples/Disruptive technology/Education as service/e-Government/HRD/Increase competitiveness/Lifelong learning/Master plan/One stop service/Policy awareness/Public participation/Secondary city/Transparent/Using BigData/Aging society/Environment restoration/Gender equality/Health/Quality of life/Safe society/Social equality/Wealth of citizen/Wellbeing.

\section{References}

1. Millard, J. Technology innovations in public service delivery for sustainable development. In Government 3.0—Next Generation Government Technology Infrastructure and Services; Springer: Berlin/Heidelberg, Germany, 2017; pp. 241-282.

2. Almaiah, M.; Al-Khasawneh, A.; Althunibat, A.; Khawatreh, S. Mobile government adoption model based on combining GAM and UTAUT to explain factors according to adoption of mobile government services. Int. J. Interact. Mob. Technol. 2020, 14, 199-225. [CrossRef]

3. Alqaralleh, B.; Al-Omari, A.; Alksasbeh, M. An integrated conceptual model for m-Government acceptance in developing countries: The case study of Jordan. Int. J. Interact. Mob. Technol. 2020, 14, 5-14. [CrossRef]

4. $\mathrm{Vu}, \mathrm{K} . \mathrm{M}$. ICT diffusion and production in ASEAN countries: Patterns, performance, and policy directions. Telecommun. Policy 2017, 41, 962-977. [CrossRef]

5. Engin, Z.; Treleaven, P. Algorithmic government: Automating public services and supporting civil servants in using data science technologies. Comput. J. 2019, 62, 448-460. [CrossRef] 
6. Hou, Y. Understanding the Design and Implementation of Civic Technologies in Resource-Limited Public Organizations. Ph.D. Thesis, The University of Michigan, Ann Arbor, MI, USA, 2018.

7. Gilman, H.R. CivicTech for urban collaborative governance. Ps-Political Sci. Politics 2017, 50, 744-750. [CrossRef]

8. Deep Knowledge Analytics. GovTech Division GovTech/E-governance Global Industry Landscape Overview 2019. Available online: https:/ / analytics.dkv.global/data/pdf/GovTech/Teaser-GovTech-E-governance-Global-Industry-Landscape-Overview2019.pdf (accessed on 8 June 2021).

9. Casalino, N.; Saso, T.; Borin, B.; Massella, E.; Lancioni, F. Digital competences for Civil Servants and Digital Ecosystems for More Effective Working Processes in Public Organizations; Springer International Publishing: Cham, Switzerland, 2020; pp. 315-326.

10. Dawes, S.; Helbig, N.; Nampoothiri, S. Workshop Report: Exploring the Integration of Data-Intensive Analytical Skills in Public Affairs Education. Available online: https:/ / www.ctg.albany.edu/publications/egovpolinet_workshopreport/ (accessed on 6 August 2021).

11. Puron-Cid, G. Information technology strategy and management curricula in public administration education in Latin America. J. Public Aff. Educ. 2017, 23, 903-924. [CrossRef]

12. Puron-Cid, G.; Gil-Garcia, J.R.; Luna-Reyes, L.F. IT-enabled policy analysis: New technologies, sophisticated analysis and open data for better government decisions. In Proceedings of the 13th Annual International Conference on Digital Government Research, Omaha, NE, USA, 4-7 June 2012; pp. 97-106.

13. Mitrovic, Z. Building open data capacity through e-skills acquisition. In Proceedings of the 3rd International Open Data Conference, Open Data Research Symposium, Ottawa, ON, Canada, 27 May 2015; pp. 28-29.

14. Van der Zwaan, B. Higher Education in 2040. A Global Approach; Amsterdam University Press: Amsterdam, The Netherlands, 2017.

15. Bynner, J. Whatever happened to lifelong learning? And does it matter? J. Br. Acad. 2017, 5, 61-89. [CrossRef]

16. Gascó-Hernández, M.; Martin, E.G.; Reggi, L.; Pyo, S.; Luna-Reyes, L.F. Promoting the use of open government data: Cases of training and engagement. Gov. Inf. Q. 2018, 35, 233-242. [CrossRef]

17. Unites Nations Thailand Sustainable Development Goals 4. Quality Education. Ensure Inclusive and Equitable Quality Education and Promote Lifelong Learning Opportunities for All. Available online: https:/ / thailand.un.org/en/sdgs/4 (accessed on 9 October 2021).

18. Royal Gazette, Thailand Announcement Concerning the National Strategy (2018-2037). Available online: http://www. ratchakitcha.soc.go.th/DATA/PDF/2561/A/082/T_0001.PDF (accessed on 21 May 2021).

19. Thailand Office of the National Economic and Social Development Board Thailand Twelfth National Economic and Social Development Plan (2017-2021). Available online: https:/ / www.greengrowthknowledge.org/national-documents/thailandtwelfth-national-economic-and-social-development-plan-2017-2021 (accessed on 3 August 2021).

20. Prime Minister's Office. Thailand Country Reform Plan (Revised Edition). Available online: http:/ /www.ratchakitcha.soc.go.th/ DATA/PDF/2564/E/044/T_0001.PDF (accessed on 3 September 2021).

21. National Electronics and Computer Technology Center. Executive Summary. Thailand Information and Communication Technology Policy Framework (2011-2020); Ministry of Science and Technology: Bangkok, Thailand, 2011; p. 29.

22. Office of Higher Education Policy and Planning. Long-Range Plan in Higher Education (2018-2037); Higher Education Commission: Bankok, Thailand, 2016.

23. Office of the National Digital Economy and Society Commission National Digital Economy and Society Development Plan and Policy (2018-2037). Available online: https:/ / www.onde.go.th/assets / portals/1/files/620425-Government\%20Gazette.PDF (accessed on 9 October 2021).

24. Commission on Higher Education. Ministry of Education Framework of the Second 15-Year Long Range Plan on Higher Education of Thailand. Available online: http:/ / www.mua.go.th/users/bpp/developplan/download/long_range_plan/executive_report_ eng.pdf (accessed on 3 August 2021).

25. Thammetar, T.; Khlaisang, J. Promoting open education and MOOCs in Thailand: A research-based design approach. In MOOCs and Open Education in the Global South; Routledge: London, UK, 2019; pp. 140-155.

26. Korner, T. Learning in 2040. Eleed 2021, 14. Available online: https://eleed.campussource.de/datenschutz (accessed on 9 September 2021).

27. Sethakul, P.; Utakrit, N. Challenges and future trends for Thai education: Conceptual framework into action. Int. J. Eng. Pedagog. 2019, 9, 8-16. [CrossRef]

28. Office of the Permanent Secretary, Ministry of Education. 12th Educational Development Plan of the Ministry of Education (2017-2021); Office of the Permanent Secretary, Ministry of Education: Bangkok, Thailand, 2016.

29. Theeraroungchaisri, A.; Khlaisang, J. Thai MOOC Sustainability: Alternative Credentials for Digital Age Learners; Europian MOOCs Stakeholders Summit-WIP: Naples, Italy; EMOOCS: Naples, Italy, 2019; pp. 203-209.

30. Becker, I.; Parkin, S.; Sasse, M.A. Combining qualitative coding and sentiment analysis: Deconstructing perceptions of usable security in organisations. In The LASER Workshop: Learning from Authoritative Security Experiment Results LASER 2016; USENIX Association: San Jose, CA, USA, 2016; pp. 43-53.

31. Graneheim, U.H.; Lundman, B. Qualitative content analysis in nursing research: Concepts, procedures and measures to achieve trustworthiness. Nurse Educ. Today 2004, 24, 105-112. [CrossRef] [PubMed]

32. Moretti, F.; van Vliet, L.; Bensing, J.; Deledda, G.; Mazzi, M.; Rimondini, M.; Zimmermann, C.; Fletcher, I. A standardized approach to qualitative content analysis of focus group discussions from different countries. Patient Educ. Couns. 2011, 82, 420-428. [CrossRef] 
33. Cho, J.Y.; Lee, E.-H. Reducing confusion about grounded theory and qualitative content analysis: Similarities and differences. Qual. Rep. 2014, 19, 1-20. [CrossRef]

34. Schreier, M. Qualitative Content Analysis in Practice; Sage Publications: London, UK, 2012.

35. Mayring, P. Qualitative content analysis. Forum Qual. Soc. Res. 2000, 1, 159-176.

36. Mayring, P. Qualitative content analysis: Demarcation, varieties, developments. Forum Qual. Soc. Res. $2019,20$.

37. Mayring, P. Qualitative Content Analysis: Theoretical Foundation, Basic Procedures and Software Solution. Available online: https:/ / www.ssoar.info/ssoar/handle/document/39517 (accessed on 4 August 2021).

38. Kondracki, N.L.; Wellman, N.S.; Amundson, D.R. Content analysis: Review of methods and their applications in nutrition education. J. Nutr. Educ. Behav. 2002, 34, 224-230. [CrossRef]

39. Basant, A.; Namita, M.; Pooja, B.; Garg, S. Sentiment analysis using common-sense and context information. Comput. Intell. Neurosci. 2015, 2015, 30.

40. Hussein, D.M.E.-D.M. A survey on sentiment analysis challenges. J. King Saud Univ.-Eng. Sci. 2018, 30, 330-338. [CrossRef]

41. Khan, K.; Baharudin, B.; Khan, A.; Ullah, A. Mining opinion components from unstructured reviews: A review. J. King Saud Univ.-Eng. Sci. 2014, 26, 258-275. [CrossRef]

42. Garcia, E. Keywords Co-Occurrence and Semantic Connectivity. An Introductory Series on Co-Occurrence Theory for Information Retrieval Students and Search Engine Marketers. Available online: http:/ / www.miislita.com/semantics/c-index-1.html (accessed on 11 April 2021).

43. Garcia, E. Targeting Documents and Terms: Using Co-Occurrence Data, Answer Sets and Probability Theory. Available online: http:/ /www.miislita.com/semantics/c-index-3.html (accessed on 6 August 2021).

44. Amin, L. How Open Is the UK Government? UK Open Governance Scorecard Results; Transparency International UK: London, UK, 2015.

45. Brown, M.M. Understanding e-government benefits: An examination of leading-edge local governments. Am. Rev. Public Adm. 2007, 37, 178-197. [CrossRef]

46. Richard, E.; David, L.F. The future of citizen engagement in cities-The council of citizen engagement in sustainable urban strategies (ConCensus). Futures 2018, 101, 80-91. [CrossRef]

47. Srivihok, V. Thailand Voluntary National Review 2021; Permanent Mission of Thailand: Bankok, Thailand, 2021.

48. Ransbeeck, W.V. What's the Difference between Civic Tech and GovTech? Available online: https://digileaders.com/whats-thedifference-between-civic-tech-and-govtech / (accessed on 3 June 2021).

49. World Bank GovTech: Putting People First. Available online: https://www.worldbank.org/en/topic/governance/brief/govtechputting-people-first (accessed on 9 April 2021).

50. Dener, C.; Nii-Aponsah, H.; Ghunney, L.E.; Johns, K.D. GovTech Maturity Index: The State of Public Sector Digital Transformation; International Bank for Reconstruction and Development: Washington, DC, USA, 2021.

51. Capeloto, A. Agency perspectives on online public records request portals. J. Civ. Inf. 2019, 1, 59-74. [CrossRef]

52. Bevis, K.; Randle, K. The management of innovation: The innovator's perception. In The ISPIM XXth International Conference; International Society for Professional Innovation: Vienna, Austria, 2009. 